\title{
WATER USE EFFICIENCY AND YIELD OF COWPEA AND NUTRIENT LOSS IN LYSIMETER EXPERIMENT UNDER VARYING WATER TABLE DEPTH, IRRIGATION SCHEDULES AND IRRIGATION METHOD
}

\author{
Binny Dasila, Veer Singh", H. S. Kushwaha, Ajaya Srivastava and Shri Ram \\ Department of Soil Science, College of Agriculture, G.B. Pant University of Agriculture and \\ Technology, Pantnagar, Udham Singh Nagar -263 145 Uttarakhand, India
}

\begin{abstract}
Lysimeter experiment was conducted at Govind Ballabh Pant University of Agriculture \& Technology, Pantnagar during summer season 2013 to study the effect of irrigation schedules and methods on yield, nutrient uptake and water use efficiency of cowpea as well as nutrient loss from silty clay loam soil under fluctuating water table conditions. The experiment was laid out in factorial randomized block design having three irrigation schedules at IW/CPE ratio of 0.3 . 0.2 and 0.15 with two irrigation methods (flood and sprinkler) and at $30 \pm 1.5,60 \pm 1.5$ and $90 \pm 1.5$ $\mathrm{cm}$ water tables replicated thrice. Maximum root length $(129.4 \mathrm{~cm})$ and root length density $\left(0.395 \mathrm{~cm} / \mathrm{cm}^{3}\right)$ were obtained when irrigation was scheduled at IW: CPE 0.3 associated with $30 \pm 1.5 \mathrm{~cm}$ water table depth using sprinkler method. Increase in water table depth and IW: CPE ratio decreased water use efficiency where IW: CPE 0.3 produced highest grain yield $\left(1411.6 \mathrm{~kg} \mathrm{ha}^{-1}\right)$ with the WUE of $1.15 \mathrm{~kg} \mathrm{ha} \mathrm{mm}^{-1}$. Significant nutrients uptake response was observed owing to variation in water table depth, irrigation schedules and methods. Analysis of lysimeter leached water showed that with deep drainage and more IW:CPE, leaching losses of N,P and $\mathrm{K}$ were more however water applied through sprinkler saved $20.1,53.7$ and $24.4 \% \mathrm{~N}, \mathrm{P}$ and $\mathrm{K}$, respectively, over flooded method. Irrigation given at IW: CPE 0.3 through sprinkler form at $60 \pm 1.5$ $\mathrm{cm}$ water table depth favours the higher grain yield and nutrient uptake by crop whereas flooded irrigation with deep water table condition accelerated nutrient leaching.
\end{abstract}

Keywords: Cowpea, water table depth, irrigation schedule and method, lysimeter, nutrient uptake, water use efficiency, nutrients loss

\footnotetext{
*Corresponding author email: veer1969_singh@yahoo.co.in
} 


\section{INTRODUCTION}

Cowpea (Vigna unguiculata (L.) Walp) is a most diverse cultivated subspecies, the widest distributed, an important food legume and versatile crop (Sanging et al., 2002). It is claimed to yield satisfactory under a diversity of climate, soil and cultural condition than most other leguminous crops. However, it is susceptible to moisture stress especially at flowering and pod filling stages (Aboamera, 2010). Moisture stress also markedly retards root hair and nodule growth and nitrogen fixation (Onuh and Donald, 2009). Although the crop responds positively to irrigation, it grows well under dry land conditions. It is grown in dry summer season in northern India under rain-fed condition, which is characterized by low and unreliable rainfall. Consequently, drought is a major abiotic stress during crop growth period that limits the performance of the crop. Therefore, the quantity of water used by the crop and lost through soil or plant (as evapotranspiration) during the growth period is a major factor for deciding yield output and nutrient losses. Low soil moisture availability, high evaporative demand and deep water table condition are more prominent during the summer season in region. As a consequence, growing cowpea in field condition is very difficult. Surface flooding method of irrigation, commonly practiced by the farmers in this region, is expensive since it causes high water loss. Drip or sprinkler irrigations may prove efficient over surface irrigation method. For efficient irrigation management in the field, water lost from plant and soil play an important role by providing information for accurately determination of crop-water requirements and irrigation schedule. Therefore, scheduling of irrigation and application of water as per the crop's requirement is very important (Campbell and Turner, 1990). Lysimeter consisting of large cans containing soil and fitted with a tight-fitting cover, and having sealed openings for plant stems is most suitable standard device to determine the water use in terms of evapotranspiration relative to a reference crop (Wright, 1991). The water used by the plants in the lysimeters is also determined by weighing the lysimeter. Research work on cowpea, especially irrigation schedule and irrigation method coupled with water table depth for cowpea cultivation by using lysimeter has not been given due consideration yet. Keeping this in view, the present study was contemplated with the objective to examine the effect of irrigation scheduling and methods in association with different water table conditions on: (i) yield and water use efficiency of cowpea, (ii) nutrient uptake by cowpea and (iii) nutrients loss from lysimeter soil through leaching.

\section{MATERIALS AND METHODS}

Filed experiments were conducted during summer season of 2013 in weighing type lysimeters installed at Norman E. Borlaug Crop Research Centre of G. B. Pant University of Agriculture and Technology, Pantnagar that situated at Tarai belt of Uttarakhand at $29^{\circ} \mathrm{N}$ latitude and $79^{\circ} 30^{\prime} \mathrm{E}$ longitude at an altitude of $243.8 \mathrm{~m}$ above mean sea level. The climate of the area is humid sub-tropical with an annual rainfall of $1433 \mathrm{~mm}$, of which $85 \%$ is received during monsoon season from June to 
September. The maximum temperature often becomes as high as $42.0 \pm 1.5{ }^{\circ} \mathrm{C}$ during summer and as low as $2.0 \pm 1.5^{\circ} \mathrm{C}$ during winter. The experimental soil, derived from the calcareous alluvium, rich in organic matter content, and classified as fine silty clay loam, mixed hyperthermic Aquic Hapludoll (Deshpande et al., 1971). The soil, used to fill the lysimeters, is silty clay loam that varies in properties as: neutral in reaction ( $\mathrm{pH}$ 7.1-7.3), medium in organic carbon (0.62-70\%), available $\mathrm{P}$ (19.6-22.4 $\mathrm{kg} \mathrm{ha}^{-1}$ ), available $\mathrm{K}\left(137.3-142.4 \mathrm{~kg} \mathrm{ha}^{-1}\right)$ and low in available $\mathrm{N}(143.5-154.2 \mathrm{~kg}$ ha $\left.{ }^{1}\right)$ due to crops grown over the years. Thirty six rectangular lysimeter tanks, $1.8 \mathrm{~m} \times 1.5 \mathrm{~m}$ in area and $1.5 \mathrm{~m}$ deep in inner side made with cement: sand: shingle (1:2:4) were placed at different heights for maintenance of different water table. In each lysimeter, a drainage galvanized iron pipe was connected to the drainage tank $(0.6 \mathrm{~m} \times 0.6 \mathrm{~m} \times 0.6 \mathrm{~m})$ which placed $3 \mathrm{~cm}$ below the bottom of lysimeter tank where at the end; a drain cock is fitted to regulate the drainage and percolation of water. Water table in the different lysimeters was maintained with water table maintenance tanks $(1.0 \mathrm{~m} \times 1.0 \mathrm{~m} \times 0.5 \mathrm{~m})$ situated at different heights and were connected with manometers for measurement of water table contribution from 30, 60 and $90 \mathrm{~cm}$ water table depths. The run-off from the lysimeters was collected in the run-off collection tanks $(0.8 \mathrm{~m} \times 0.8 \mathrm{~m} \times 0.8 \mathrm{~m})$ through a pipe connected with the lysimeter tanks. The experiment consisted of three factors: water table depths, irrigation schedule and irrigation method; each factor comprised three treatments. There were thus 18 treatment combinations, which were laid out in Factorial Randomized Block Design with two replications. In the lysimeters total 6,4 and 3 irrigations were applied through surface flooding and sprinkler methods at IW: CPE (depth of irrigation water: cumulative pan evaporation) of $0.3,0.2$ and 0.15 , respectively, under water table depths of $30 \pm 1.5,60 \pm 1.5$ and $90 \pm 1.5 \mathrm{~cm}$. Crop evapotranspiration, ET $(\mathrm{mm})$ was determined from water input and losses as

$$
E T_{n}=R_{n}+I_{n}+W T c_{n}-D_{n} \pm \Delta S_{n}
$$

where R is rainfall $(\mathrm{mm})$, I is irrigation $(\mathrm{mm}), \mathrm{WTc}$ is water table contribution $(\mathrm{mm}), \mathrm{D}_{\mathrm{n}}$ is drainage $(\mathrm{mm})$, and $\Delta \mathrm{S}$ is changes in soil-water storage $(\mathrm{mm})$. The subscript ' $n$ ' indicates time interval in days. Rainfall data was taken from a weather observatory near the experiment site. The amount of flood irrigation was $30 \mathrm{~mm}$ measured through Parshal flume. For sprinkler method, the $20 \mathrm{~mm}$ of irrigation was applied to lysimeters. The prescribed water table depths in the lysimeter were maintained during the course of crop period through water table maintenance pipes connected at the bottom of the lysimeter tanks. Nutrients in the form of N, P and K were applied in the lysimeters at 25,50 and $20 \mathrm{~kg} \mathrm{ha}^{-1}$, respectively, prior to sowing of cowpea seeds. Pant Lobia-1 an extra early-maturing variety of cowpea that performs well in agro- Tarai soils, was sown on 06 March 2013 at spacing of $30 \times 15$ $\mathrm{cm}$. All required cultural operations were done as per standard agronomic practices. The experimental data was analyzed statistically for factorial randomized block design by employing SPSS-16 statistical package (SPSS, Inc., Chicago, IL, USA) to 
evaluate and quantify the source of variation. The treatment means were compared at a significance level of 5 per cent $(\mathrm{P}=0.05)$.

\section{RESULTS AND DISCUSSION}

\section{Growth and yield attributes}

Irrigation schedules and irrigation methods significantly influenced the plant height of cowpea but water table depths caused insignificant variation in the plant height (Table 1). The plant highest was at $60 \pm 1.5 \mathrm{~cm}$ water table depth than $30 \pm 1.5$ $\mathrm{cm}$ and $90 \pm 1.5 \mathrm{~cm}$ water table depth. However at IW: CPE of 0.3 and 0.2 , the plant height was statistically at par but it gave 24.1-27.1\% higher plant height over IW: CPE 0.15. Maintenance of adequate soil moisture by irrigation at IW: CPE of 0.3 established higher plant height over other soil moisture regimes. Sprinkler method of applying irrigation produced $14.52 \mathrm{~cm}$ more plant higher than the flood method. The highest number of nodules (21.33) was obtained from cowpea plant that grew with $60 \pm 1.5 \mathrm{~cm}$ water table depth. This nodule number differed significantly different significantly from the mean number of nodules (13.17) recorded from the plants that grew with $90 \pm 1.5 \mathrm{~cm}$ water table depth but was at par (20.33) with $30 \pm 1.5 \mathrm{~cm}$ water table depth. Reduction in soil moisture availability within the root zone reduced root nodulation of the crop indicating that water is an essential input for root nodulation and shortage of which reduced formation of nodules. This finding is inconformity with the observations of Serraj (2003) and Onuh and Donald (2009). There was a significant difference in the number of pods per plant under the three irrigation schedules. But water table depths and irrigation methods did not influence the number of pods per plant significantly. Synchronizing irrigation at IW: CPE of 0.3 and 0.2 with the vegetative and flowering stages of the crop might yield higher number of pods per plant. Water table depth, irrigation schedules and irrigation methods had significant effect on dry weight of root and root-length density. When the water table was close to soil surface, sufficient water was available for root growth and, consequently higher root mass and density were obtained compared to the situation where water table was far below the soil surface. Despite of the maximum dry weight of roots $(1.07 \mathrm{~g})$ at $60 \pm 1.5 \mathrm{~cm}$ water table depth, water table maintained at $30 \pm 1.5 \mathrm{~cm}$ provided the highest root-length density. Similar trends were also obtained in the dry weight of root and root-length density with irrigation schedules and irrigation methods. Zhang et al. (2004) (for wheat) and Jamal et al. (2010) (for barley) also reported that frequent irrigation arrested higher root weight

and root-length density while Kumar et al. (2014) observed higher growth and yield parameters in cowpea when irrigated through sprinkler as compared to flood method. 
Table 1. Growth and yield parameters of cowpea as influenced by water table depth, irrigation schedule and irrigation methods in lysimeter experiments

\begin{tabular}{|c|c|c|c|c|c|c|}
\hline $\begin{array}{l}\text { Factors and } \\
\text { treatments }\end{array}$ & $\begin{array}{l}\text { Plant } \\
\text { height } \\
(\mathrm{cm})\end{array}$ & $\begin{array}{l}\text { No. of } \\
\text { nodules/ } \\
\text { plant }\end{array}$ & $\begin{array}{l}\text { No. of } \\
\text { pods/plant }\end{array}$ & $\begin{array}{l}\text { Pod } \\
\text { length } \\
(\mathrm{cm})\end{array}$ & $\begin{array}{l}\text { Root dry } \\
\text { weight/pla } \\
\text { nt (g) }\end{array}$ & $\begin{array}{l}\text { Root- } \\
\text { length } \\
\text { density } \\
\left(\mathrm{cm} / \mathrm{cm}^{3}\right)\end{array}$ \\
\hline \multicolumn{7}{|c|}{ Water table depth $(\mathrm{cm})$} \\
\hline $30 \pm 1.5 \mathrm{~cm}$ & 71.42 & 20.33 & 11.90 & 13.58 & 0.84 & 0.35 \\
\hline $60 \pm 1.5 \mathrm{~cm}$ & 74.83 & 21.33 & 12.15 & 14.46 & 1.07 & 0.31 \\
\hline $90 \pm 1.5 \mathrm{~cm}$ & 74.46 & 13.17 & 11.85 & 13.19 & 0.89 & 0.28 \\
\hline S.Em \pm & 2.00 & 0.70 & 0.30 & 0.26 & 0.04 & 0.004 \\
\hline $\mathrm{CD}(\mathrm{P}=0.05)$ & NS & 2.10 & NS & 0.78 & 0.13 & 0.012 \\
\hline \multicolumn{7}{|c|}{ Irrigation schedules } \\
\hline $\begin{array}{l}\text { IW: } \mathrm{CPE}= \\
0.3\end{array}$ & 79.88 & 18.67 & 12.08 & 13.62 & 0.99 & 0.32 \\
\hline $\begin{array}{l}\text { IW: } \mathrm{CPE}= \\
0.2\end{array}$ & 78.00 & 18.33 & 12.48 & 13.86 & 0.98 & 0.32 \\
\hline $\begin{array}{l}\text { IW: } \mathrm{CPE}= \\
0.15\end{array}$ & 62.83 & 17.83 & 11.34 & 13.75 & 0.83 & 0.30 \\
\hline S.Em \pm & 2.00 & 0.70 & 0.30 & 0.26 & 0.04 & 0.004 \\
\hline $\mathrm{CD}(\mathrm{P}=0.05)$ & 5.96 & NS & 0.89 & NS & 0.13 & 0.012 \\
\hline \multicolumn{7}{|c|}{ Irrigation methods } \\
\hline Flood & 66.31 & 18.11 & 11.92 & 13.41 & 0.81 & 0.31 \\
\hline Sprinkler & 80.83 & 18.44 & 12.01 & 14.08 & 1.06 & 0.32 \\
\hline S.Em \pm & 1.63 & 0.57 & 0.24 & 0.21 & 0.03 & 0.003 \\
\hline $\mathrm{CD}(\mathrm{P}=0.05)$ & 4.87 & NS & NS & 0.63 & 0.10 & 0.010 \\
\hline
\end{tabular}

IW: CPE, depth of irrigation water: cumulative pan evaporation; S.Em, standard error of mean;

$\mathrm{CD}$, critical difference

\section{Grain yield, water use efficiency and nutrient uptake}

Grain yield had a significant response to different levels of water table depths, irrigation schedules and irrigation methods. Significant higher grain yield was obtained under $60 \pm 1.5 \mathrm{~cm}$ water table depth $\left(1389.3 \mathrm{~kg} \mathrm{ha}^{-1}\right)$, IW:CPE $0.3(1411.6 \mathrm{~kg}$ $\left.\mathrm{ha}^{-1}\right)$ and sprinkler method (1304.3 $\left.\mathrm{kg} \mathrm{ha}^{-1}\right)$; these observed yields were 10.4-18.9\%, $5.7-32.1 \%$ and $5.2 \%$ more than the other treatments of the corresponding factors (Table 2). Suresh et al. (2013) reported higher pod yield of ground nut when irrigation was applied at IW: CPE of 1.0 compared to IW: CPE of 0.6 and 0.8 and 
with sprinkler method. Dabhi et al. (1998) obtained higher grain yield of green gram irrigated with sprinkler method compared to surface method. The increase in pod yield under sprinkler irrigation was mainly due to high frequency of irrigation which in turn maintained soil moisture content in the root zone at adequate level throughout the crop period. Water table maintained at $60 \pm 1.5 \mathrm{~cm}$ depth produced $10.4 \%$ more grain yield by saving $12.3 \%$ water use compared to $30 \pm 1.5 \mathrm{~cm}$ water table depth. The heavy textured soil (silty clay loam) and shallow water table $(30 \pm 1.5 \mathrm{~cm})$ retarded activity of roots due to inadequate oxygen in the root zone while for the deeper water table $(90 \pm 1.5 \mathrm{~cm})$, lack of inadequate soil-moisture resulted in low grain yield. Decline in grain yield was significant with the decrease in irrigation frequency from IW: CPE of 0.3 to 0.15 . The increased grain yield was mainly due to adequate soilmoisture availability to the growth stages of crop and increased nutrients uptake throughout the crop growth stages since both the inputs exerted beneficial effect on yield contributing factors. Water use also had a positive correlation with the grain yield. Changes in water table, irrigation frequency and method of irrigation had significant effects on water use by the crop. There was a higher consumptive use of water at shallow water table condition and more irrigation frequency than at deeper water table condition and less irrigation frequency. The higher consumptive use of water attributed to more evapotranspiration loss due to better canopy development and greater nutrient availability to the crop. The observed results are inconformity with the findings of Singh et al. (2006) and Abu and Malgwi (2012). Water use efficiency, WUE, was found to be influenced significantly only with the variation in water table depth. It showed inverse and parallel relations with evapotranspiration under fluctuating water tables and irrigation frequency, respectively, but no definite trend of WUE was obtained with grain yield. The lower WUE is ascribed to reduction in grain yield under shallow water table and limited irrigations. Alteration in water table depth, irrigation schedules and irrigation methods significantly influenced N, P and K uptake by the crop. The impact of different water table depths and irrigation schedules on $\mathrm{P}$ and $\mathrm{K}$ uptake were, in general, similar to $\mathrm{N}$ uptake. Compared to $30 \pm 1.5 \mathrm{~cm}$ water table depth, IW: CPE of 0.2 and flood method of irrigation, the $60 \pm 1.5 \mathrm{~cm}$ water table depth, IW: CPE of 0.3 and sprinkler method of irrigation provided $13.5,5.5$ and $12.2 \%$ more uptake of $\mathrm{N}$, respectively; $16.0,0.8$ and $8.7 \%$ more uptake of $\mathrm{P}$, respectively and $17.3,8.9$ and $12.1 \%$ more uptake of $\mathrm{K}$, respectively. The results showed that $30 \pm 1.5 \mathrm{~cm}$ water table depth reduced nutrient uptake compared to $60 \pm 1.5 \mathrm{~cm}$ water table depth. However increase in irrigation frequency and irrigation applied through sprinkler enhanced the NPK uptake by the plants. Al-Kaisi and Yin (2003) also reported higher N uptake by maize crop at IW: CPE of 1.0 compared to IW: CPE of 0.6 . Higher uptake of N, P and K by tomato under drip irrigation compared to flood irrigation was also reported by Agrawal et al. (2004). 
Table 2. Grain yield and water use efficiency of cowpea, and nutrient uptake by the crop as influenced by water table depth, irrigation schedules and irrigation methods in lysimeter experiments

\begin{tabular}{|c|c|c|c|c|c|c|}
\hline Treatments & $\begin{array}{c}\text { Grain } \\
\text { yield (kg } \\
\left.\mathrm{ha}^{-1}\right)\end{array}$ & $\begin{array}{l}\text { Water use } \\
(\text { ET in } \\
\text { mm) }\end{array}$ & $\begin{array}{l}\text { Water use } \\
\text { efficiency } \\
(\mathrm{kg} / \mathrm{ha} / \mathrm{mm})\end{array}$ & $\begin{array}{l}\text { N uptake } \\
\left(\mathrm{kg} \mathrm{ha}^{-1}\right)\end{array}$ & $\begin{array}{l}\text { P uptake } \\
\left(\mathrm{kg} \mathrm{ha}^{-1}\right)\end{array}$ & $\begin{array}{l}\text { K uptake } \\
\left(\mathrm{kg} \mathrm{ha}^{-1}\right)\end{array}$ \\
\hline \multicolumn{7}{|c|}{ Water table depth $(\mathrm{cm})$} \\
\hline $30 \pm 1.5 \mathrm{~cm}$ & 1258.2 & 1359.9 & 0.92 & 98.7 & 5.75 & 38.1 \\
\hline $60 \pm 1.5 \mathrm{~cm}$ & 1389.3 & 1192.4 & 1.16 & 112.0 & 6.67 & 44.7 \\
\hline $90 \pm 1.5 \mathrm{~cm}$ & 1168.2 & 953.1 & 1.22 & 94.2 & 5.22 & 41.4 \\
\hline S.Em. \pm & 16.1 & 14.7 & 0.02 & 1.8 & 0.12 & 0.8 \\
\hline $\mathrm{CD}(\mathrm{P}=0.05)$ & 47.9 & 42.1 & 0.06 & 5.2 & 0.35 & 2.3 \\
\hline \multicolumn{7}{|c|}{ Irrigation schedules } \\
\hline $\begin{array}{l}\text { IW: } \mathrm{CPE}= \\
0.3\end{array}$ & 1411.6 & 1239.5 & 1.15 & 112.7 & 6.33 & 46.6 \\
\hline $\begin{array}{l}\text { IW: } \mathrm{CPE}= \\
0.2\end{array}$ & 1335.6 & 1159.6 & 1.17 & 106.8 & 6.28 & 42.8 \\
\hline $\begin{array}{l}\text { IW: } \mathrm{CPE}= \\
0.15\end{array}$ & 1068.4 & 1106.3 & 0.98 & 85.4 & 5.02 & 34.8 \\
\hline S.Em \pm & 16.1 & 14.7 & 0.02 & 1.8 & 0.12 & 0.8 \\
\hline $\mathrm{CD}(\mathrm{P}=0.05)$ & 47.9 & 42.1 & NS & 5.2 & 0.35 & 2.3 \\
\hline \multicolumn{7}{|c|}{ Irrigation methods } \\
\hline Flood & 1239.5 & 1151.2 & 1.10 & 95.8 & 5.63 & 39.0 \\
\hline Sprinkler & 1304.3 & 1185.8 & 1.11 & 107.5 & 6.12 & 43.7 \\
\hline S.Em \pm & 13.1 & 12.0 & 0.02 & 1.5 & 0.10 & 0.7 \\
\hline $\mathrm{CD}(\mathrm{P}=0.05)$ & 39.1 & 34.3 & NS & 4.3 & 0.29 & 1.9 \\
\hline
\end{tabular}

IW: CPE, depth of irrigation water: cumulative pan evaporation; S.Em, standard error of mean;

$\mathrm{CD}$, critical difference

\section{Nutrients removal through leachate}

Availability of the nutrients in the lysimeter soils prior to sowing of cowpea seeds did not vary considerably due to the impact of variation in water table depth, irrigation schedules and irrigation methods applied in previous mustard crop in which these factors were same except irrigation schedules (IW: CPE). Analysis of nutrients in the collected leachate indicated that nutrients in the leachate were significantly affected with the variation in water table depth, irrigation frequency and irrigation method (Table 3). The $\mathrm{N}-\left(\mathrm{NO}_{3}{ }^{-}+\mathrm{NH}_{4}{ }^{+}\right), \mathrm{P}$ and $\mathrm{K}$ contents in the leachate increased with the increase in water table depth and frequency of irrigation under flood 
irrigation resulting more risk of nutrient ( $\mathrm{N}, \mathrm{P}$ and $\mathrm{K}$ ) build up or contamination of ground water with nutrients. The difference in leached nutrient in the treatments was primarily because of differences in root density and shoot biomass of the crop resulting from different rates of water availability to the plants (Loper et al., 2013). Also in case of more water availability in soil, nutrients had been set free without being used by the plants. These findings are also accorded with Behrendt et al. (2004). The $\mathrm{NO}_{3}-\mathrm{N}$ in the drained solution for all treatment options was higher than $\mathrm{NH}_{4}-\mathrm{N}$ because of the higher solubility and lower affinity of $\mathrm{NO}_{3}{ }^{-}$ions for the adsorption sites in the soil. Significant higher (about 1.2 folds) $\mathrm{N}-\left(\mathrm{NO}_{3}{ }^{-}+\mathrm{NH}_{4}{ }^{+}\right), \mathrm{P}$ and $\mathrm{K}$ leaching occurred at deeper water table $(90 \pm 1.5 \mathrm{~cm}$ depth) than shallow water table $(30 \pm 1.5 \mathrm{~cm}$ depth) probably due to the higher starting available nutrients in the lower water table (Fang et al., 2006). On the other hand, 42.3, 50.0 and 56.4\% losses of $\mathrm{N}-\left(\mathrm{NO}_{3}{ }^{-}+\mathrm{NH}_{4}{ }^{+}\right), \mathrm{P}$ and $\mathrm{K}$, respectively, were recorded with 6 irrigations scheduled for IW: CPE of 0.3; these nutrient losses found maximum as compared to different water table depths and irrigation methods. The greater removal of nutrients was associated with the increasing amount of water availability in soil, drainage of water and mineralization of nutrients and their reduced uptakes by the plants. Considering the maximum and minimum removal of nutrients under different water table depths, irrigation schedules and irrigation methods, the losses of nutrients were found in the order of $\mathrm{K}>\mathrm{P}>\mathrm{N}-\left(\mathrm{NO}_{3}{ }^{-}+\mathrm{NH}_{4}{ }^{+}\right)$, where removal of $\mathrm{K}$ ranged from 24.1 to $56.4 \%$. This showed that $\mathrm{K}$ is subjected to rapid leaching and hardly retained by soil followed by $\mathrm{P}$ and $\mathrm{N}\left(\mathrm{NO}_{3}-\mathrm{N}+\mathrm{NH}_{4}-\mathrm{N}\right)$.

Table 3. Initial available nutrient and nutrients removal through leachate as influenced by water table depth, irrigation schedules and irrigation methods in lysimeter experiments

\begin{tabular}{|c|c|c|c|c|c|c|}
\hline \multirow[t]{2}{*}{ Treatments } & \multicolumn{3}{|c|}{ Initial available nutrients $\left(\mathrm{kg} \mathrm{ha}^{-1}\right)$} & \multicolumn{3}{|c|}{$\begin{array}{l}\text { Nutrients removed through leachate } \\
\qquad\left(\mathrm{kg} \mathrm{ha}^{-1}\right)\end{array}$} \\
\hline & $\mathrm{N}$ & $\mathrm{P}$ & $\mathrm{K}$ & $\begin{array}{c}\mathrm{N}-\left(\mathrm{NO}_{3}^{-}+\right. \\
\left.\mathrm{NH}_{4}^{+}\right)\end{array}$ & $\mathrm{P}$ & $\mathrm{K}$ \\
\hline \multicolumn{7}{|c|}{ Water table depth $(\mathrm{cm})$} \\
\hline $30 \pm 1.5 \mathrm{~cm}$ & 137.9 & 21.8 & 149.2 & 52.05 & 2.78 & 3.16 \\
\hline $60 \pm 1.5 \mathrm{~cm}$ & 141.1 & 22.6 & 148.4 & 57.43 & 2.95 & 3.28 \\
\hline $90 \pm 1.5 \mathrm{~cm}$ & 143.2 & 22.8 & 147.1 & 64.23 & 3.39 & 3.92 \\
\hline S.Em. \pm & 2.91 & 0.35 & 2.06 & 0.58 & 0.16 & 0.14 \\
\hline $\mathrm{CD}(\mathrm{P}=0.05)$ & NS & NS & NS & 1.65 & 0.48 & 0.39 \\
\hline \multicolumn{7}{|c|}{ Irrigation schedules } \\
\hline IW: $\mathrm{CPE}=0.3$ & 127.5 & 22.0 & 149.4 & 69.62 & 3.48 & 4.30 \\
\hline IW: $\mathrm{CPE}=0.2$ & 149.5 & 22.4 & 146.9 & 55.12 & 3.31 & 3.30 \\
\hline IW: $\mathrm{CPE}=0.15$ & 145.3 & 22.8 & 148.4 & 48.98 & 2.32 & 2.75 \\
\hline
\end{tabular}




\begin{tabular}{lcccccc}
\hline S.Em \pm & 2.91 & 0.35 & 2.06 & 0.58 & 0.16 & 0.14 \\
CD $(\mathrm{P}=0.05)$ & 8.69 & NS & NS & 1.65 & 0.48 & 0.39 \\
Irrigation methods & & & & & & \\
Flood & 131.7 & 22.4 & 149.0 & 64.39 & 4.15 & 3.93 \\
Sprinkler & 149.8 & 22.4 & 147.4 & 51.42 & 2.92 & 2.97 \\
S.Em \pm & 2.38 & 0.29 & 1.68 & 1.00 & 0.14 & 0.11 \\
CD $(\mathrm{P}=0.05)$ & 7.09 & NS & NS & 2.86 & 0.39 & 0.32 \\
\hline
\end{tabular}

IW: CPE, depth of irrigation water: cumulative pan evaporation; S.Em, standard error of mean;

$\mathrm{CD}$, critical difference

\section{CONCLUSION}

Scheduling irrigation at IW: $\mathrm{CPE}=0.2$ associated with $60 \pm 1.5 \mathrm{~cm}$ water table depth and sprinkler method of irrigation is desirable to obtain high growth and yield attributes of cowpea. However, $60 \pm 1.5 \mathrm{~cm}$ water table depth and increased number of irrigation (IW: $\mathrm{CPE}=0.3$ ) applied through sprinkler method proved beneficial for grain yield and nutrient uptake for the crop. Increase in water table depth and frequency of irrigation applied through flood method enhanced nutrient removal; the loss of nutrients was in the order of $\mathrm{K}>\mathrm{P}>\mathrm{N}-\left(\mathrm{NO}_{3}{ }^{-}+\mathrm{NH}_{4}{ }^{+}\right)$with maximum removal of $\mathrm{K}$ ranging from $24.1-56.4 \%$. So, $60 \pm 1.5 \mathrm{~cm}$ water table depth accompanied with IW: CPE of 0.3 and sprinkler method of irrigation application is the best management option for grain yield and nutrient uptake of cowpea. The shallow water table $(30 \pm 1.5$ $\mathrm{cm}$ ) with 4 irrigations, however led to the least nutrient removal through leaching.

\section{REFERENCES}

Aboamera, M. A. 2010. Response of cowpea to water deficit under semi-portable sprinkler irrigation system. Misr Journal of Agricultural Engineering, 27(1): 170-190

Abu, T. and Malgwi, W. B. 2012. Effects of irrigation regime and frequency on soil physical quality, water use efficiency, water productivity and economic returns of paddy rice. ARPN Journal of Agricultural and Biological Science, 7(2): 86- 99

Agrawal, B., Sharma, H. G. and Pandey, A. 2004. Nutrient uptake affected by irrigation method and micronutrient applications in tomato hybrid. Vegetable Science, 31 (1): 7882

Al-Kaisi, M. M. and Yin, X. 2003. Effects of nitrogen rate, irrigation rate, and plant population on corn yield and water use efficiency. Agronomy Journal, 95:1475-1482

Behrendt, A., Schalitz, G., Mueller, L. and Schindler, U. 2004. Effects of different drain depths on nutrient leaching of lowland soils in Northeast Germany. Drainage VIII, Proceedings of the $8^{\text {th }}$ International Drainage Symposium. 21-24 March, Sacramento, California, S. 241-245 
Campbell, O. S. and Turner, N. C. 1990. Plant- soil- water relationships. p. 49085 - 49659. In: G. J. Hoffman, T. A. Howell and K. H. Solomon (ed.), Management of farm irrigation systems. The ASAE, 2950 Niles Road St. Josheph, M I

Dabhi, B. M., Patel, J. C. and Solanki, R. C. 1998. Response of summer green gram to irrigation methods and varying moisture regimes. Legume Research, 21(2): 96-100

Deshpande, S. B. Fehrenbacher, J. B. and Ray, B. W. 1971. Mollisols of Tarai region Uttar Pradesh, Northern India, 2. Genesis and classification. Geoderma, 6 (3): 195-201

Fang, Q., Yu, Q., Wang, E., Chen, Y., Zhang, G., Wang, J. and Li, L. 2006. Soil nitrate accumulation, leaching and crop nitrogen use as influenced by fertilization and irrigation in an intensive wheat-maize double cropping system in the North China Plain. Plant Soil, 284: 335-350

Jamal, Y. A., Ayed, M. A. and Hani, M. S. 2010. Variation in root water and nitrogen uptake and their interactive effects on growth and yield of spring wheat and barley genotypes. International Journal of Botany, 6 (4): 404-413

Kumar, R., Kumar, R., Yadav, N. K. and Kushwaha, H. S.2014. Studies on evapotranspiration by vegetable pea under different water table conditions. Bioinfolet, 11 (38): 861-863

Loper, S. J., Shober, A. L., Wiese, C., Denny, G. C., and Stanley, C. D. 2013. Nutrient leaching during establishment of simulated residential landscapes. Journal of Environmental Quality, 42: 260-270

Onuh, M. O. and Donald, K. M. 2009. Effect of water stress on the rooting, nodulation potentials and growth of cowpea (Vigna unguiculata (L) WALP). Science World Journal, 4(3): 31-34

Sanging, N. G., Tholta, P. and Dashiell, K. 2002. Effectiveness of rhizobia nodulating recent promiscuous soybean selections in the moist savannah of Nigeria. Soil Biology and Biochemistry, 32:127-133

Serraj, R. 2003. Effects of drought stress on legume symbiotic nitrogen fixation: physiological mechanisms. Indian Journal of Experimental Biology, 41(10):1136-1141

Singh, R. J., Idnani, L. K. and Rai, R. K. 2006. Grain yield, water use efficiency, economics and soil moisture extraction pattern of summer green gram (Vigna radiata L.) as influenced by planting and irrigation methods, irrigation schedules and VAM inoculation. Annals of Agricultural Research, 27(3): 306-310

Suresh, K., Balaguravaiah, D., Ramulu, V. and Rao, C. H. S. 2013. Comparative efficiency of sprinkler irrigation over check basin irrigation in groundnut at different irrigation schedules. International Journal of Plant, Animal and Environmental Sciences, 3 (2): 9 $-13$

Wright, J. L.1991. Using weighing lysimeters to develop evapotranspiration crop coefficients. p. 191-199. In Allen, R. G., Howell, T. A., Pruitt, W.O., Walter, I. A. and Jensen, M. E. (ed.), Lysimeters for evapotranspiration and environmental measurements, ASCE, New York, NY

Zhang, X., Pei, D. and Chen, S. 2004. Root growth and soil water utilization of winter wheat in the North China plain. Hydrological Processes, 18: 2275-2287 